\title{
Agenda for the 26th General Assembly of the European Association for the Study of Diabetes to be held in Copenhagen, Bella Center 12th September, 1990 from 16.30-17.00 hours
}

\section{Minutes of the 25 th General} Assembly, Lisbon 1989

\section{Reports}
a) President
b) Honorary Treasurer
c) Honorary Auditors
d) Honorary Secretary
e) Editor in Chief-Diabetologia Dr. Hellerström
Dr. P.Lefèbvre
Dr. J. Ward
Dr. Attali
Dr. Muggeo
Dr. R. Landgraf

3. Elections
a) Vice President
in place of Dr. Balasse 1990-1993
retiring by rotation

to be approved, printed

in the Volume of $\mathrm{Ab}$ stracts b) Honorary Secretary 1991-1994

c) Council members 1991-1994

4. Postgraduate Education Sub-Committee

5. Study Groups

6. Any other business in place of Dr. Landgraf retiring by rotation in place of Dr. De Leiva, Dr. Froland, Dr. Tiengo, Dr. Hahn retiring by rotation

Dr. Assal to report 